原著

高血圧症，脳血管障害における経過および

\title{
予後と脳循環動態
}

\author{
警友総合病院内科（院長石田二郎博士） \\ 岡田 年弘 高木 康行* \\ 斉藤 佳雄 山岡 三郎
}

\section{CEREBRAL HEMODYNAMICS AND PROGNOSIS IN PATIENTS WITH HYPERTENSION AND CEREBROVASCULAR DISEASE}

\author{
Toshihiro Okada, Yasuyuki Takagi, Yoshio Sarto and Saburo Yamaoka \\ Department of Internal Medicine, Keiyu General Hospital, Yokohama, Japan
}

\begin{abstract}
概要 381例の高血圧症，脳血管障害につき $\mathrm{N}_{2} \mathrm{O}$ 法による脳循環測定をserialに行ない，その経過，子 後と脳循環動態との関連を求めた，高血正症を種々の因子により検討すると，高血压患者の媨血流量 （CBF）に最も大きな影響を与えるものは血圧管理の良否であつた，肥満そのものの影響は少ないが，

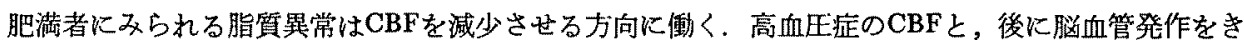
たしたるのの発症前のCBFとの間には有意差を認めなかつた．高血圧から脳血管発作を抗こすと，頭 蓋内出血や重症，中等症の閉箐性脳血管障㕩では CBF は有意差をもつて 減少する．発作 $2 \sim 3$ カ月 後の CBF は閉塞性脳血管障害重症例で改善がみられず，中等症では発作直後の CBF は低值で

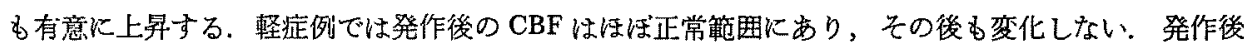
1 カ月以上たつても CBF が 低值にとどまるものから 死亡，再発作例の生ずることが多く認められ た.
\end{abstract}

緒言

脳の機能と代謝が脳循環に大きく依存している ことはいらまでもない. $\mathrm{N}_{2} \mathrm{O}$ 法による脳循環測定 がこの方面の研究に役立つて, 各種病態に括ける 脳の血行動態と代謝状態を明らかにしてきたこと る良く知られている。

しかし今日まで同一症例について病態の進展す る様相を脳循環，代謝面から钼察した報告は未だ

[昭和 47 年 9 月 18 日受稿]

(*現在 済生会中央病院神経内科)

本諭文の要旨の一部は第 $9 ， 10 ， 11 ， 12$ 回日本神経学 会総会, 第32,33，35回日本循環器学会総会, 第 9 回 日本脈管学会総会打よび第68回日本内科学会講演会 において発表した。
なされていない，高血圧から脳血管障害へと進展 する病態は $\mathrm{N}_{2} \mathrm{O}$ 法による脳偱環病態面にも反映さ れるに違いないと考え，著者らは，多数の高血压 患者について脳循環測定を行ない，その後長年月 にわたり経過を追求した。これは，高血圧，脳血 管障害の予後にかんし重大な示唆をあたえるもの と思われるので，ここに報告する。

対象ならびに研究方法

対象とした症例は，昭和36年 2 月より46年 2 月 まで整友病院を受診した 381例で，このららアン ケートまたは直接診察により予後を調査しえたも のは354例である．年令は35才より87才まで平均 
56.8才（予後にかんしては56.6才，以下（）内は 同じ), 男 274（252），女 107 (102) 例，疾患 別では高血圧症 183 ( 176) 例, 脳血管障害 198 （177）例でその内訳は頭蓋内出血34（34）例, 閉塞珄脳血管障害 164（143）例である. 脳循環 測定は同一例につき $1 \sim 7$ 回平均 2 回行ない，総 計 715（679） 回，初回測定よりの観察期間は $1 \sim 10$ 年平均 41 (45.8) カ月で, 死亡例では平均 25.6 力月. 脳循環测定は $\mathrm{N}_{2} \mathrm{O}$ 法慶大変法により， 血液ガスはILメーターを用い，血清コレステロ ールはZak-Henly法, 血清中性脂肪はCarlson法に よつた.

脳血管障害は臨床的には天幕上障害で，うち閉 塞性脳血管障害は䯑道液に異常所見なく，脳血管撮 影でspace taking lesionを認めないものとし，頭 蓋内出血はく子膜下出血か脳出血の症例で, 䯣液 は血性もしくはキサントクロミ一をしめしたもの とした。本論文中に用いられる測定諸量用語, 単位は脳血流量 (CBF) $\mathrm{ml} / 100 \mathrm{~g}$ 脳/分, 脳血管 抵抗 (CVR) $\mathrm{mmHg} / \mathrm{ml} / 100 \mathrm{~g}$ 脳/分, 脳酸素消費量 $\left(\mathrm{CMRO}_{2}\right) \mathrm{ml} / 100 \mathrm{~g}$ 脳/分, 平均動脈血圧 (MABP) mm $\mathrm{mg}$, 脳動静脈血酸素較差 $\left(\mathrm{AVO}_{2}\right) \mathrm{mm} \mathrm{Hg}$ などで, 脳動（静）脈血酸素（炭酸カス）分氏を $\mathrm{Pa}(\mathrm{v}) \mathrm{O}_{2}$ $\left(\mathrm{CO}_{2}\right)$ とした.

\section{成 績}

A. 高血圧症, 脳血管障害における経過と脳循 環諸量の推移

1. 高血圧症に叔ける脳循環諸量の推移

高血圧症の5ち脳血管障害のない48例につき， 1 回目の測定から12力月以上平均31.5力月後に 2 回目の測定を行ない, 脳循環諸量の变動を観察し た(表 1 ).この期間のMABPに変化なく, $\mathrm{PaCO}_{2}$ も 不变である. CBFは平均值で $47.4 \pm 5.5$ より 45.4

表 1。高血王症における脳循環諸量の推移（48例）

\begin{tabular}{c|c|c|c|c|c|c|c}
\hline & 年 & $\mathrm{CBF}$ & $\mathrm{MABP}$ & $\mathrm{CVA}$ & $\mathrm{CMRO}_{2}$ & $\mathrm{CRO}$ & $\mathrm{PaCO}_{2}$ \\
\hline \multirow{2}{*}{ 前 } & $\begin{array}{c}54.6 \\
\pm 8.0\end{array}$ & $\begin{array}{c}47.4 \\
\pm 5.5\end{array}$ & $\begin{array}{c}118 \\
\pm 15\end{array}$ & $\begin{array}{c}2.58 \\
\pm 0.45\end{array}$ & $\begin{array}{c}3.12 \\
\pm 0.58\end{array}$ & $\begin{array}{c}0.97 \\
\pm 0.06\end{array}$ & $\begin{array}{c}36.3 \\
\pm 3.0\end{array}$ \\
\hline \multirow{2}{*}{ 後 } & $\begin{array}{c}57.0 \\
\pm 8.4\end{array}$ & $\begin{array}{c}45.4 \\
\pm 7.4\end{array}$ & $\begin{array}{c}114 \\
\pm 14\end{array}$ & $\begin{array}{c}2.60 \\
\pm 8.63\end{array}$ & $\begin{array}{c}3.16 \\
\pm 0.70\end{array}$ & $\begin{array}{c}1.00 \\
\pm 0.08\end{array}$ & $\begin{array}{c}37.1 \\
\pm 3.4\end{array}$ \\
\hline
\end{tabular}

士7.4とやや減少しているが, 推計学的には有意 の変化ではなかつた $(0.05<\mathrm{P}<0.1)$. CVRは不 変, $\mathrm{CMRO}_{2}$ は平均值 $3.12 \pm 0.58$ と $3.16 \pm 0.70$ で 変動がみられない。

これら高血圧症48例を以下述べる因子によつて わけ，それぞれの脑循環諸量の推移を検討した。

\section{a. 年令, 血王}

高血圧症48例を初回測定時の年令によつてわけ ると，54才以下ではCBFは観察期間平均 33.5 力 後に多变化を認めず, $\mathrm{CMRO}_{2}$ 子平均值で減少す るが有意ではなかつた，55才以上でも平均29.8カ 月でCBFの推移に有意差なく, $\mathrm{CMRO}_{2}$ も不变で あったまた，初回測定時のMABPでわけると， 129以下の37例ではCBFは47.3土 5.5から45.8土 7.3と 3.2\%の低下をしめすにすぎないが， 130 以上の11例ではCBFは47.6士 5.0より44.1土7.2 と $7.3 \%$ の減少で，血王の高い群にCBFはやや减 少する傾向をみるが，推計学的には有意ではなか つた.

\section{b . 肥満}

標準体重に比し20\%以上の体重增加を肥満とし た. 観察期間を通じて肥浾であつたるのおよび 肥满に移行したものは高血圧症48例中15例で，平 均 29.5力月の㽙察で 9 例にCBFの減少を認めた が，有意の差はなかった。

一方，肥満のない33例では平均32.5力月の間， CBFの推移に有意差はみられなかつた。

その他 $\mathrm{CMRO}_{2}, \mathrm{MABP}, \mathrm{PaCO}_{2}$ は而群とも变化 はみられない。

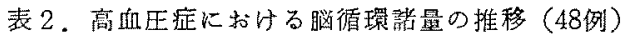

$$
\text { 一管理による分類一 }
$$

\begin{tabular}{|c|c|c|c|c|c|c|}
\hline \multicolumn{2}{|c|}{ (A) 管理良好 } & 26例 & \multicolumn{4}{|c|}{ （银䨛期間 $29.0 \pm 17.3$ 力月） } \\
\hline & 年 令 & CBF & MABP & CVA & CMRO: & $\mathrm{PaCO}_{2}$ \\
\hline 前 & $55.5 \pm 0.9$ & $46.7 \pm 09$ & $120_{ \pm 15}$, & 2.6010 & $3.07+06$ & $37.0 \pm 3$ \\
\hline 後 & $57.8 \pm 8$ & 47.0 .0 .3 & $117+106$ & $2.61 \% 0$, & $3.17 * 0$ & $37.4 \pm 2$ \\
\hline
\end{tabular}

\begin{tabular}{|c|c|c|c|c|c|c|}
\hline \multicolumn{2}{|c|}{ (B) 管理不良 } & 22例 & \multicolumn{4}{|c|}{ （钼察期閶 $34.5=13$ 功月) } \\
\hline & 年 令 & CBF & MABP & CVR & $\mathrm{CMRO}_{2}$ & $\mathrm{PaCO}:$ \\
\hline 前 & $53.6 \pm 26$ & $48.2 \div 3.9$ & $116: 4.1$ & 2.46 .0 & $3.19 \pm 0.4$ & $36.4 \pm 2.1$ \\
\hline 缕 & $56.7 \pm 1 .$. & $43.5 * 3$ & $\| A:=0.8$ & $2.58=$ & $3.04=0$ & $35.5_{t+1}$ \\
\hline
\end{tabular}


表 3 ，血清脂質異常之睬環循諸量の推移

\begin{tabular}{|c|c|c|c|c|c|c|c|c|c|}
\hline & 例数 & 年 令 & t察期閒 & 時期 & $\mathrm{CBF}$ & MABP & CVR & CMAO, & $\mathrm{PaCO}_{2}$ \\
\hline $\begin{array}{ll}\text { 能 } & \text { 就 } \\
\text { 正常群 }\end{array}$ & 9 & $\begin{array}{c}56.6 \\
5.8\end{array}$ & $\begin{array}{c}\text { (A) } \\
23.1 \\
\\
1 \$ 5,0\end{array}$ & \begin{tabular}{|l} 
前 \\
後 \\
\end{tabular} & $\begin{array}{r}48.2 \\
47.1 \\
4.1 \\
\pm .3 .3\end{array}$ & \begin{tabular}{|l|}
111 \\
120 \\
\end{tabular} & 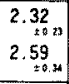 & $\begin{array}{c}3.31 \\
\pm 0.010 \\
3.05 \\
\pm \neq .7 n\end{array}$ & $\begin{array}{r}37.3 \\
36.7 .4 \\
3.1 .4 \\
t .1\end{array}$ \\
\hline $\begin{array}{ll}\text { 脂 } & \text { 磶 } \\
\text { 異常群 }\end{array}$ & 17 & {$\left[\begin{array}{r}56.1 \\
14.5\end{array}\right]$} & $\begin{array}{r}21.7 \\
\neq .5 \\
\end{array}$ & $\begin{array}{l}\text { 前 } \\
\text { 後 }\end{array}$ & $\begin{array}{r}45.5 \\
\pm 4 \\
41.6 \% \\
t .3 \\
\end{array}$ & \begin{tabular}{|l|}
116 \\
114 \\
114 \\
\\
\end{tabular} & \begin{tabular}{|c|}
2.58 \\
$z 8.48$ \\
2.82 \\
$z 0.4$
\end{tabular} & \begin{tabular}{l|}
3.10 \\
\pm 0.02 \\
2.77 \\
\pm 0.02 \\
\end{tabular} & 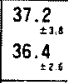 \\
\hline Тур $\mathrm{II}]$ & 3 & $\begin{array}{r}60.7 \\
\quad: .1 \\
\end{array}$ & $\begin{array}{r}20.7 \\
11.4\end{array}$ & 前 & $\begin{array}{l}46.9 \\
71.30 \\
413 \\
\vdots\end{array}$ & 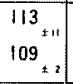 & \begin{tabular}{l|}
2.43 \\
\pm 0.040 \\
2.52 \\
\pm 0.9
\end{tabular} & \begin{tabular}{|c|}
3.51 \\
$t 6.51$ \\
2.51 \\
$t 0.4$.
\end{tabular} & $\begin{array}{c}38.0 \\
\pm 1.9 \\
35.8 \\
\pm 2.5\end{array}$ \\
\hline Typ in & 6 & {$\left[\begin{array}{c}56.3 \\
\pm 5.6\end{array} \mid\right.$} & $\begin{array}{cc}21.2 \\
. & \pm 1.4\end{array} \mid$ & $\begin{array}{l}\text { 前 } \\
\text { 後 } \\
\end{array}$ & $\begin{array}{c}45.6 \\
\pm 0.8 \\
40.2 \\
\pm .1 .\end{array}$ & $\begin{array}{l}127 \\
112 \\
112 \\
=21\end{array}$ & $\begin{array}{l}2.82 \\
2.97 \\
2.97\end{array}$ & \begin{tabular}{|c|}
2.88 \\
\pm 0.72 \\
2.82 \\
\pm 0.4 \\
\end{tabular} & $\begin{array}{r}37.8 \\
37.1 . \\
37.2 \\
\end{array}$ \\
\hline (Typ $N$ & 8 & 54.1 & {$\left[\begin{array}{r}22.5 \\
\ldots \\
\end{array}\right.$} & $\begin{array}{l}\text { 前 } \\
\text { 後 }\end{array}$ & $\begin{array}{c}45.0 \\
\quad: .1 \\
42.7 \\
=2.1 \\
\end{array}$ & $\begin{array}{ll}109 & \pm 12 \\
118 & \pm .4\end{array}$ & $\begin{array}{c}2.46 \\
\pm 0.4 \\
2.82 .4 \\
\quad 0.44 \\
\end{array}$ & 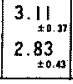 & $\begin{array}{l}36.5 \\
36.2\end{array}$ \\
\hline
\end{tabular}

$* P<0.05$

\section{c. 管理 (表 2)}

ここでいら管理良好とは規則的に受䛦し，服薬 を励行したものをいい，これに基づき高血圧症 48 例を 2 群にわけて検討した。管理良好の26例で は，観察期間平均29.0力月でCBF平均值は46.7士

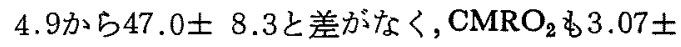
0.63 と $3.17 \pm 0.90$ で変化を認めない.

しかし管理不良の 22例では観察期間平均 34.5

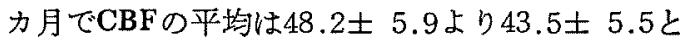
$10 \%$ も減少し，この推移は $1 \%$ 以下の危険率で推

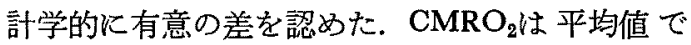
低下しているが有意でなく，両者の年令，MABP， $\mathrm{PaCO}_{2}$ には差を認めていない。

d. 脂質 (表 3)

高血圧症26例につき 1 年以上の経過でその前後
の脳循環諸量と血清脂質との関係を検討した．空 腹時コレステロール $200 \mathrm{mg} / \mathrm{dl}$ ，中性脂肪 $100 \mathrm{mg} / \mathrm{dl}$ 以上を高値とし，FredricksonのタイプII， III，IV とをあわせ脂質異常群として他の脂質正常群と比 較した，正常の 9 例では平均23.1カ月の経過で $\mathrm{CBF}$ に変化なく $\mathrm{CMRO}_{2}$ も不変であつた。一 方，脂質異常群17例では21.7カ月の経過でCBFは $45.5 \pm 4.7$ より $41.6 \pm 7.3$ とやく $8.1 \%$ 減少し， これは推計学的にも5\%以下の危険率で有意の低 下であった。 しかし $\mathrm{CMRO}_{2}$ には有意差を認めて いない.

2. 高血圧症に括ける無事故群と脳事故群との 比較

高血圧症で脳循環湘定を行ない，その後経過観 察して12力月以上平均49.6力月間に脳血管発作, 心筋硬塞などを和こさなからた無事故群と，脳血 管事故を和こした脳事故群とを比較すると（表 4), 無事故群 139例の初回測定CBFは平均 $48.4 \pm$ 7.4， $\mathrm{CMRO}_{2}$ は 3.06士0.59であり，一方平均 21.1 力月後に閉塞性脳血管障害を生した12例の

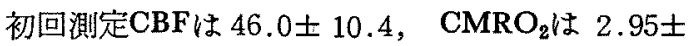
0.88 で無事故群との間に有意差を認めていない. また平均 29.8 カ後に頭蓋内出血を呫こした 6 例 （くも膜下出血，脳出血打の打の 3 例）の事故前 のCBFおよびCMRO れず，高血圧無事故群，閉塞性脳血管障害を生じ た群とも有意差をしめさなかつた。

表 4. 高血压症における無事故群と脳事故群との比較

1. 無擎故群

\begin{tabular}{c|c|c|c|c|c|c|c|c|c|c}
\hline & 例数 & 年命 & 瑅察期間 & $\mathrm{CBF}$ & $\mathrm{MABP}$ & $\mathrm{CVR}$ & $\mathrm{CMRO}_{2}$ & $\mathrm{CRO}$ & $\mathrm{PaCO}_{2}$ & $\mathrm{PrO}_{2}$ \\
\hline 事故なし & \multirow{2}{*}{139} & $\begin{array}{c}53.0 \\
\pm 8.6\end{array}$ & $\begin{array}{c}49.6 \\
\pm 24.2\end{array}$ & $\begin{array}{c}48.4 \\
\pm 7.4\end{array}$ & $\begin{array}{c}119 \\
\pm 17\end{array}$ & $\begin{array}{c}2.52 \\
\pm 0.53\end{array}$ & $\begin{array}{c}3.06 \\
\pm 0.59\end{array}$ & $\begin{array}{c}0.99 \\
\pm 0.07\end{array}$ & $\begin{array}{c}36.7 \\
\pm 3.7\end{array}$ & $\begin{array}{c}32.9 \\
\pm 2.7\end{array}$ \\
\hline
\end{tabular}

2.脳事故群

\begin{tabular}{|c|c|c|c|c|c|c|c|c|c|c|}
\hline & 例数 & 年令 & 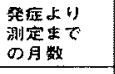 & $\mathrm{CBF}$ & MABP & OVR & CMRO: & CRO & $\mathrm{PaCO}_{2}$ & $\mathrm{PW}_{2}$ \\
\hline 顆蓋 & 6 & $\begin{array}{r}56.3 \\
\pm 5.8 \\
\end{array}$ & $\begin{array}{r}29.8 \\
\quad \pm 19.7 \\
\end{array}$ & $\begin{array}{c}54.2 \\
\pm 7.2 \\
\end{array}$ & $\begin{array}{c}119 \\
\pm 26 \\
\end{array}$ & $\begin{array}{l}2.27 \\
\pm 0.68 \\
\end{array}$ & $\begin{array}{l}3.36 \\
\pm 0.49 \\
\end{array}$ & $\begin{array}{l}0.97 \\
\pm 0.0 \mathrm{~B} \\
\end{array}$ & $\begin{array}{r}40.5 \\
\pm 5.5 \\
\end{array}$ & $\begin{array}{r}35.0 \\
\pm 2.3 \\
\end{array}$ \\
\hline 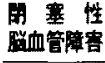 & 12 & $\begin{array}{r}63.3 \\
\pm 18.2 \\
\end{array}$ & $\begin{aligned} 21.1 & \pm 18.2\end{aligned}$ & $\begin{array}{l}46.0 \\
\pm 10.4\end{array}$ & $\begin{array}{c}109 \\
\pm 21\end{array}$ & $\begin{array}{l}2.51 \\
\pm 0.80\end{array}$ & $\begin{array}{l}2.95 \\
\pm 0.88 \\
\end{array}$ & $\begin{array}{l}1.00 \\
\pm 0.07\end{array}$ & $\begin{array}{c}35.9 \\
\pm 2.3\end{array}$ & $\begin{array}{c}33.7 \\
\pm 3.7\end{array}$ \\
\hline
\end{tabular}




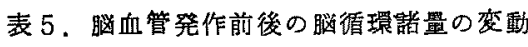

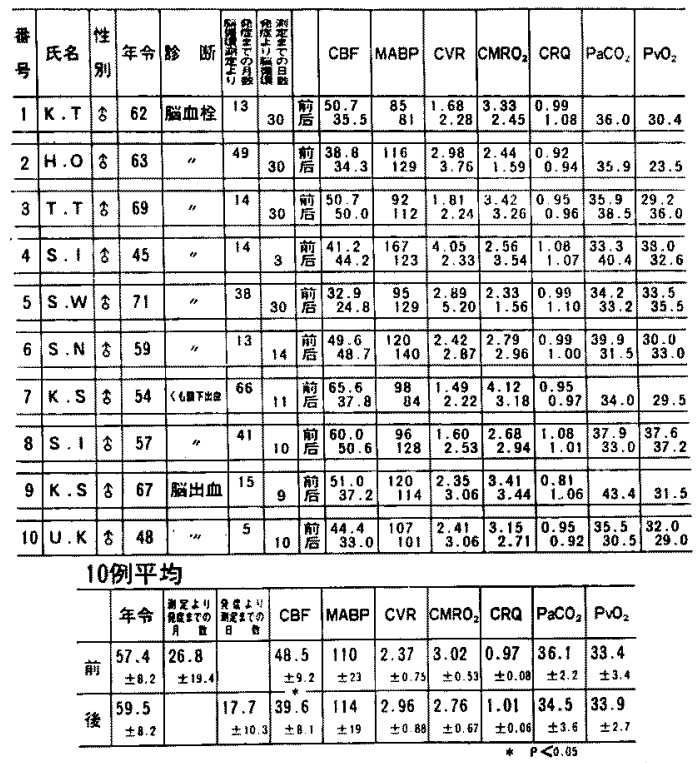

3. 脳血管発作前後の脳循環諸量の変動

脳血管発作前に脳循環測定を行ない，発症 1 カ 月以内に再び測定し点た10例の発作前後の脳循環 諸量の変動をしめす(表 5 ). 症例は脳血栓 6 , くむ 膜下出血 2 , 脳出血 2 例で，これら発症前のCBF は平均48.5土 9.2, 発症後平均17.7日には $39.6 \pm$ 8.1 之 $18.3 \%$ 減少し，この変化は危険率 $5 \%$ 以
下で推計学的に有意である．CVRは平均值で上昇 しているが有意でなく， $\mathrm{CMRO}_{2}$ は $3.02 \pm 0.53$ よ り2.76士0.67と減少するが，有意の変化ではなか つた. MABP, $\mathrm{PvO}_{2}, \mathrm{PaCO}_{2}$ に差はみられなか つた.

次にこれら変化を閉塞性脳血管障害と頭蓋内出 血とにわけて検討した。

a 、閉塞性脑血管障害 (図 1)

前述した脳血栓 6 例に，発症前に測定し発症後 2 カ月以内, 扣よび 2 年以上たつて测定し壳た各 1 例を加え計 8 例についてそのCBFの变動をみる と, 隇少 5 , 不変 3 例である.

与ち発症後 2 力月以内の 7 例火ついてCBFの変

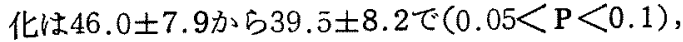

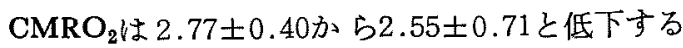
が有意ではなかつた。このうち意識障害を伴い重 篤な麻疾をのこした 3 例のCBFはいずれも著しく 減少して括り，意識障害なく麻痺も軽い軽症例で は， $\mathrm{CBF}$ の減少わ10\%以内にとどまっている。

\section{b ，頭蓋内出血（因 2 )}

く子膜下出血 2 , 脳出血 2 例について発作前, 発作後 2 週間以内に脳循環を測定した.

発作はいずれも急激に意識障害をきたした もので， $\mathrm{CBF}, \mathrm{CMRO}_{2}$ は発作後著明に低下した

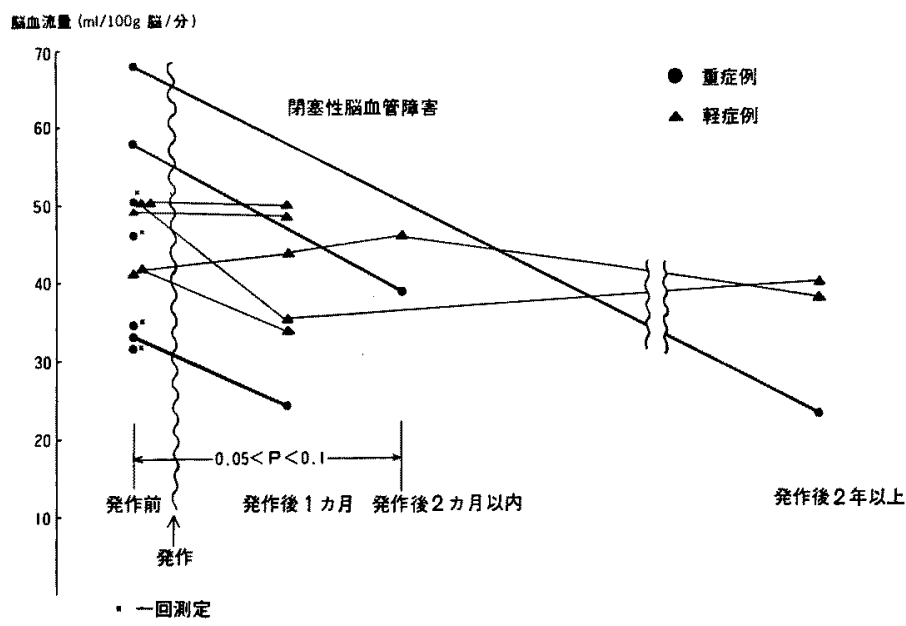

図 1，䁖血管発作前後の脳血流量の変動 


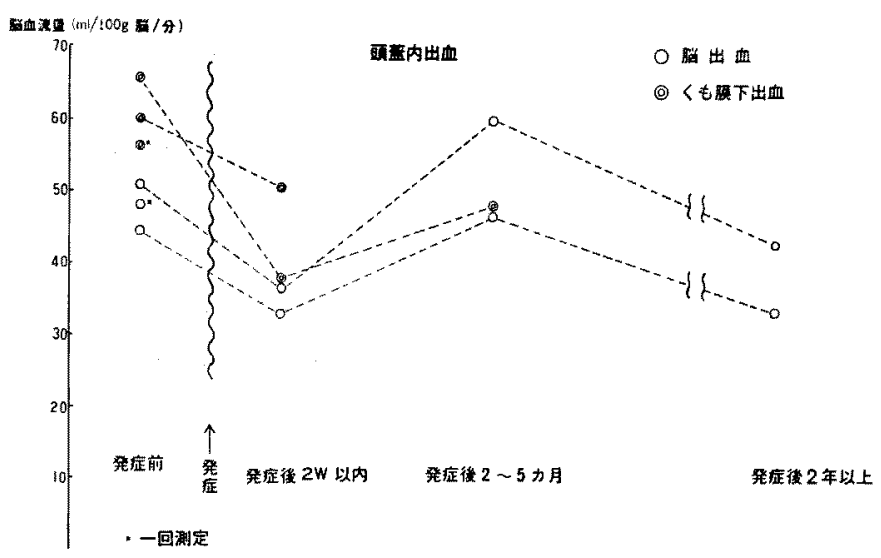

图 2，睬血管発作前後の睬血流量の变動

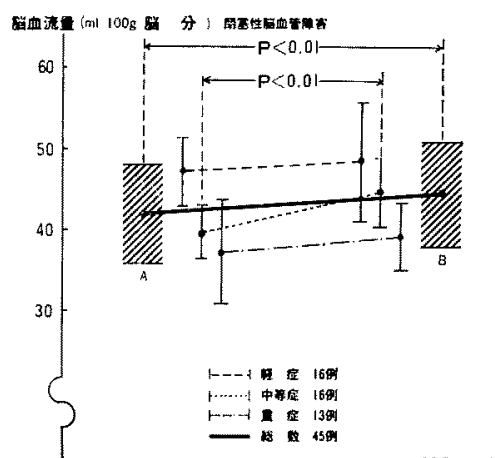

A：発作後 1 力月以内以測定世当的の （幵均12日）

$\mathrm{B}$ ： 笔作後 1 力月後に第 2 回測定世るるの (平均58日)

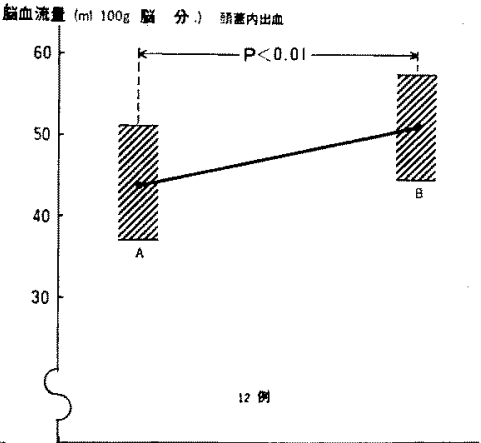

A： 発作後 1 カ月以内に測定せるもの (平均12日)

B： 発作後 1 力月後に第 2 回測定せるもの (平均80日)

図 3. 腷血管発作後の䁖血流量の推移

が $(55.3 \pm 8.1 \rightarrow 39.7 \pm 6.6, \quad 3.34 \pm 0.52 \rightarrow 3.07 \pm$ 0.09), 発作後回復のみられた 3 例は，2〜5力 月後にCBFは明らかに改善している.さらに 2 年 以上の長い期間には再び減少しているのがみられ t.

4. 脳血管発作後の脳循環諸量の推移

脳血管発作後 1 力月以内に脳循環を測定し，そ の後経過を追つて再度湘定しえた症例につきCBF の恋動をしめす（図３）。

閉塞性胆血管障害45例では，発作後 1 力月以内
平均12日でCBFの平均は $41.8 \pm 6.2$, 発作後平均 58 日には $44.5 \pm 6.6$ と危険率 $1 \%$ 以下で有意の上 昇を認めた. このらら発作後 2 週以内に日常生活 に支障のない程回復した軽症16例では，発作直後 もCBFは47.2土 4.3とかなりの高值をしめし，発 作後 148 日にもあまり変動していない.一方, 発 作時意識障害を伴い1 カ月後る歩行不能であつた 重症13例では，発作時CBFは37.5土 6.3と著明に 減少しており，発作後 117 日にも回復はほとんど みられない. 


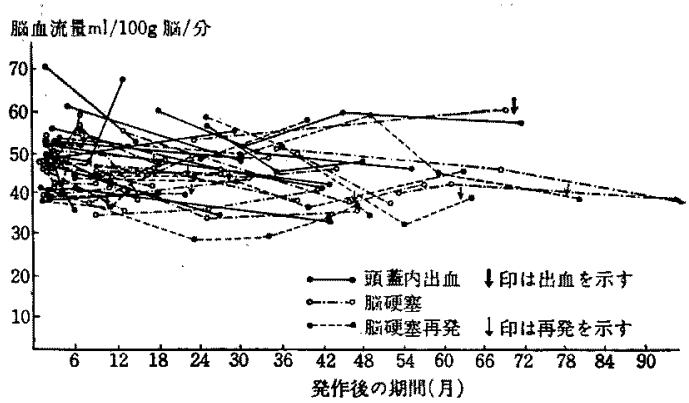

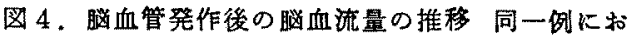
ける長期䅐察（46例）

しかしこれら中間の中等症では発作後のCBFは $39.8 \pm 3.2$ と著明に減少しているが，平均69日後 には44.6士 4.2 と有意に上昇することが認められ た。

頭蓋内出血12例（くも膜下出血1例を含む）で

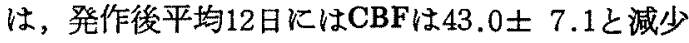
しているが，平均80日後には50.9土 6.5 と有意の 上昇を認めた。CVRは2.67士0.43より2.32士0.39 と有意の減少であつた。

5. 脳血管発作後のCBFの長期観察

脳血管発作後 1 カ月以後長期観察した症例の $\mathrm{CBF}$ の推移を図示する(図 4). 症例は頭蓋内出 血, 閉塞性脳血管障害をあわせ46例で, 発作後 2 〜3年まではほぼ一定の血流を保つているが，そ の後CBFはやや低下してゆくすのが多いことに気 付く.

\section{B. 高血圧症，脳血管障害における予後と媨循} 環諸是

1. 全例における死亡事故之脳循環諸量

対象の 354例全生存 295例と全死亡59例にわ け初回の 測定值を 比較した. 生存例CBFの平均 $46.6 \pm 8.0$ と死亡例の $43.6 \pm 9.3$ との間には $1 \%$ 以下の危険率で有意の差が認められる. $\mathrm{CMRO}_{2}$ は生存 $3.03 \pm 0.64$, 死亡 $2.85 \pm 0.67$ で有意差を認 めない. $\mathrm{MABP}, \mathrm{PaCO}_{2}, \mathrm{PvO}_{2}$ に差がなかつた。 しかし年令は死亡例により高令であつた（表 6 ）.

このように患者の予後とCBFとは死亡の有無と いう事実と関連性のあることがわかつたので，脳

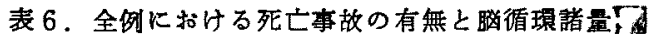

\begin{tabular}{|c|c|c|c|c|c|c|c|}
\hline & 1) & 年余 & $\mid \begin{array}{c}\mathrm{CBF} \\
(=1 / 1000 \mathrm{~s} / \mathrm{s} / \mathrm{A})\end{array}$ & $\begin{array}{l}\text { MABP } \\
\text { (mMH })\end{array}$ & 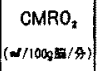 & $\begin{array}{c}\mathrm{PaCO}_{2} \\
\left(\mathrm{mmH}_{\mathrm{g}}\right)\end{array}$ & 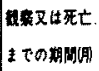 \\
\hline 全生存用 & 295 & 56 & $\begin{array}{l}46.6 \\
\pm 8.0\end{array}$ & $\begin{array}{l}116 \\
\pm 17\end{array}$ & $\begin{array}{l}3.03 \\
\pm 0.64\end{array}$ & $\begin{array}{c}36.5 \\
\pm 3.5\end{array}$ & $\begin{array}{l}45.8 \\
\pm 23.6\end{array}$ \\
\hline 全死亡网 & 59 & 62 & $\begin{array}{r}43.6 \\
\pm 9.9\end{array}$ & $\begin{array}{l}117 \\
\pm 20\end{array}$ & $\begin{array}{l}2.85 \\
\pm 0.67\end{array}$ & $\begin{array}{r}37.5 \\
\pm 3.9\end{array}$ & $\begin{array}{l}25.6 \\
\pm 20.3\end{array}$ \\
\hline
\end{tabular}

表 7, 高血压症に括讨る死亡事故の有繁と睬血流量

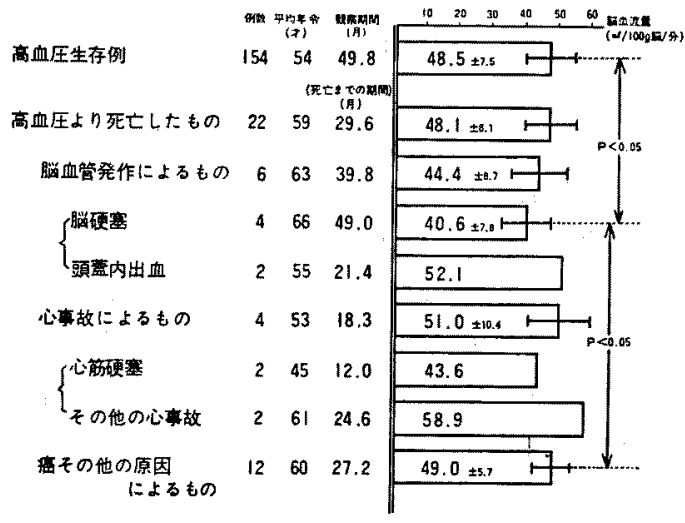

循環を測定した時期によつてCBFが，患者の予後 とどのよらに関係があるかを検討した。

2. 高血圧症のCBFからみた長期予後

a. 生存例と死亡例の比較（表 7).

高血圧症 176例中, 生存 154例の C B F の平均 は48.5土 7.5, 経過中癌その他の原因に上る死亡 12例のCBFは49.0土 5.7で差を認めない：しかし 脳循環測定後平均 49.0 カ月に脳硬塞を㧊こし死亡 した 4 例のCBF $40.6 \pm 7.8$ とは，5\%以下の危険 率で有意の差がある．さらにこの 4 例は，癌その 他の原因により死亡した 12 例とも5\%以下の危険 率で有意差を認めた。

b. 生存例々脳，心事故例との比較

高血王で腷，心死亡事故のなかつた 139例で は, 観察期間平均 49.6カ月でCBFの平均は48.4士 7.4 , 高血圧より平均 21.1 力後に脳血管発作を 
おこした18例のCBFは 46.5土9.5で差を認めな い.さらにこの18例を閉塞性脳血管障害12例（脳 硬塞 9 , 一過性脑虚血発作 3 例) と頭蓋内出血 6 例にわけそれぞれのCBFを比較してみてす同様で あつたまた高血圧より心筋硬塞を叔こした 5 例 とも差を認めなかつた。

これら閉塞性脳血管障害12例の初回測定より発 症までの期間とCBFとの関係をみると，発症は CBFのかなり低值をしめするの（31.5）からむみ られるとともに正常なるの（68.1）からむおこつ ており，また発症時の重症度とも関連がみられな からた.

3. 脳血管発作後 1 カ月以内に測定したCBFか らみた長期予後

a. 生存例と死亡例の比較（表 8)

閉塞性脑血管障害で平均 34.6 力月生存してる71 例のCBFの平均は42.6土 6.6で, 発作後臥床のま ま平均 2.4 力月後に死亡した 3 例, 平均 23.7 力月 後に脳硬塞再発に上り死亡した 3 例とも CBFは明 らかに低下して蛙り，これら6例のCBFの平均 $37.1 \pm 7.4$ は生存例との間に $5 \%$ 以下の危険率で 有意差を認める。しかし頭蓋内出血生存例とその 死亡例との間には有意差を認めていない。

b. 再発の有無に上る比較

閉塞性腦血管障害で平均 32.4 カ月後も事故のな かつた58例のCBFは平均 $42.9 \pm 6.3 て ゙ ， 22.1$ カ

表 8. 莤血管発作後の 死亡事故の有無と発作後 1 力月以内 9 睬血流量

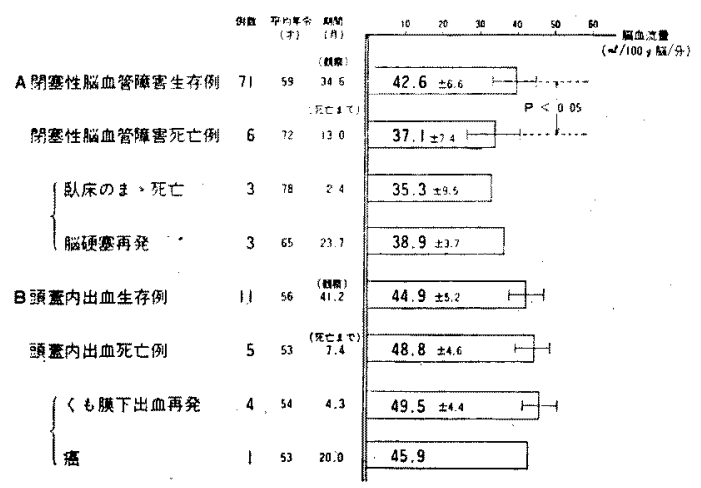

表 9、瞄血管発作後の死亡事故の有無之発作後 1 力月以後 $の$ 媨血流量

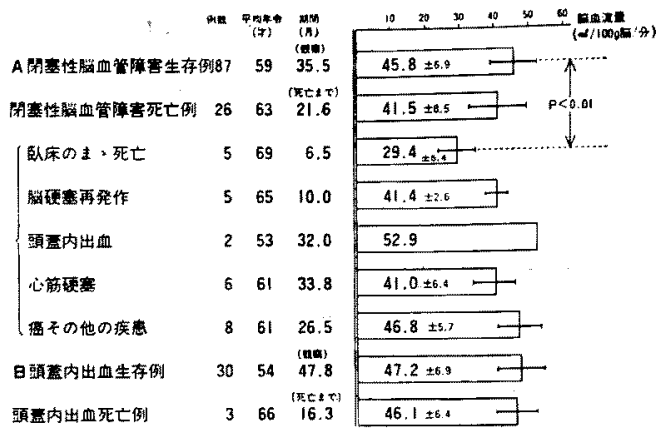

後に再発作をおこした16例のCBF40.6士 7.5 とは 差を認めない，頭蓋内出血例です無事故例（CBF

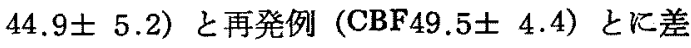
はみられなかつた。

4. 脳血管発作後 1 カ月以上たつて 測定した CBFからみた長期予後

\section{a . 生存例と死亡例の比較（表 9)}

閉塞性腷血管障害で, 平均35.5力月生存してい る87例の発作後 1 カ月以上して測定したCBFは平 均 $45.8 \pm 6.9 ， 21.6$ 力月後に死亡した26例のCBF と有意差を認めていない，しかし死亡例のうち発 作後も平均 6.5 力月臥床のま死亡した重症 5 例 のCBFは極めて低く，その平均値29.4土 5.4は生 存例之の危険率 $1 \%$ 以下で有意の差がある. また， 脳硬塞再発作死亡 5 例，心筋硬塞発症死亡 6 例の CBFはいずれる低下しているが，生存例との間に 有意差を認めなかつた。また癌その他の疾患で死 亡した 8 例のCBF \&生存例と差を認めていない。

表10，脳血管発作後の再発の有無と発作後 1 力月 以後の譄血流量

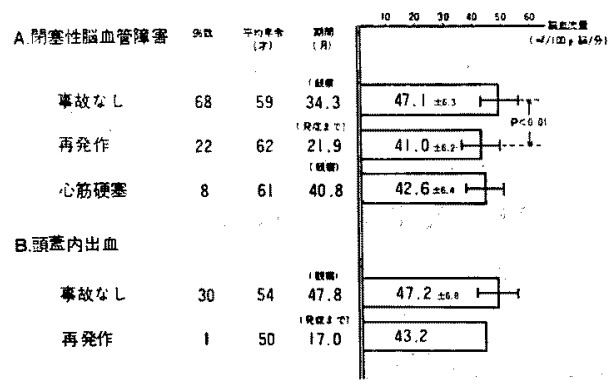




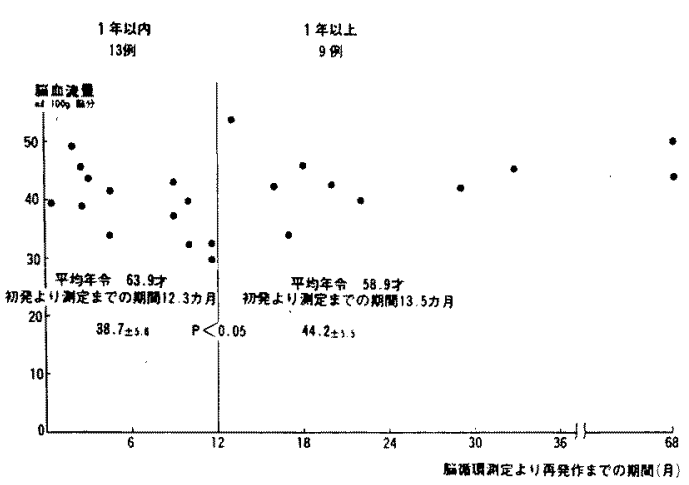

図 5、譄循環測定より脳硬塞再発までの期間と脑 血流量

頭蓋内出血例では，平均 47.8 月生存している30 例のCBF と16.3カ月後に死亡した 3 例のCBF とに は有意差はなかった。

b．再発の有無による比較（表10，図 5)

閉塞性脳血管障害で平均34.3カ月間事故なく， 日常生活可能なもの68例のCBFは平均 $47.1 \pm 6.3$ で，平均21.9力月後に再発作をみた 22 例のCBF $41.0 \pm 6.2$ との間に危険率 $1 \%$ 以下で推計学的に 有意の差を認めた。心筋硬塞を抽こした 8 例，癌 その他の原因による死亡 5 例は，日常生活可能例 との間に差を認めていない。

さらに再発までの期間とCBFについて検討する $\zeta$, 脳循環測定後 1 力年以内平均 6.2 力月後に脳 硬塞再発したものは13例あり，その平均年令は 63.9 才, $\mathrm{CBF}$ の平均は38.7士5.6, 脳循環測定後 1 力年以上平均 30.1 力月後に再発した 9 例の年令 は58.9才，CBFは平均44.2士 5.5で，1 カ年以内 に再発したるのと 1 カ年以上たつて再発したもの とのCBFには，明らかな差を認めた $(\mathrm{P}<0.05)$.

\section{A. 高血圧症の脳循環}

高血圧症の脳循環についてはすでに多数の報告 があるが，同一症例を追つて検索した報告は見当 らない，田崎”は，高血圧症のみでは脳血流代謝に 有意の障害はみられないが，年令増加に伴いCBF は直線的に下降するとのべ，後藤2)は中年以後の 高血压では，血圧 $170 \mathrm{~mm} \mathrm{Hg}$ まではCBFは増加する
が，それ以上では逆に減少することをしめして いる，今回著者らの成績では高血圧症をfollow up し，平均31.5力月の閒隔をおいて前後に測定する と，CBFでは平均値の減少をみるのみで推計学的 には有意な変化はみられなかった。これは症例 数，観察期間が充分でないことによるとる考えら れる，艺こで種々の要因により，高血圧症のCBF の推移がどのように影響されるかを検討した。

年令, 高血圧の程度とCBFの変化には特に関連 性をみいたしえなかつたが，高血圧経過観察中， これを管理面でわけると，管理不良群のCBFは有 意差をるつて低下しているのを認め，一方良好群 では何らの差をみなかつた，高血圧症の管理は終 局的には高血王性心，腎，脳血管疾患の予防を目 的として扣り，今日，血圧の管理は薬物によるも のが主体となつている，中島鬲 は長期降圧薬の効 果につき，降王薬で継続治療された群は，その中 断, 不定期使用, 非使用群らに比し有意に生存率 が高く予後のよいことを統計的に明らかにし，勝 木") あ久山町研究でこれを認め, 長期継続治療の 必要性を強調している。 また, Kojimahara ${ }^{5}$ は両腎 動脈狭窄による高血圧ラットに降圧薬を連続投与 すると，血圧上昇も，動脈の類線維素变性の発生 も抑制されるが，隔週の断続投与で血圧をゆさぶ ると，動脈病変はむしろ増強，内膜に潰瘍形成す ら認められるという．著者らの成績でも，高血圧 管理の不充分な例でュントロールされない高血圧 の持続が脳循環障害の一因となりらることがしめ された。

肥満については一般に動脈硬化が多く, 脳循環 障害の一因とされるが，著者らは肥満の有無が脳 循環障害をむたらすものでなく，肥満者にみられ る高中性脂肪血症の発現頻度が，非肥满者に比し 明らかに多い事実より，血清脂質異常を介して脳 循環が障害されるるのと推論したが，今回の成績 でも高血圧症のCBFの推移に非肥满群，肥満群と る変化はみられなかつた。

ここに動脈硬化の進展因子として脂質代謝異常 が問題となる．特定集団の長期食事療法で脂質代 
謝の改善がみられ，動脈硬化汇基づく虚血性疾患 の発生が和さ文られる事実的より高脂血症を食 事，薬物によつて是正しようとする試みがなさ れ，中村》 は脳血管障害を将来発生せしめない予 防的処置として，血清脂質の目標をより低い値に 向けるべさだとしている. 儀武( は脳循環と血清 脂質との関連を求め, 中性脂肪と $\mathrm{CBF}, \mathrm{CMRO}_{2}$ と の間に負の相関をみ，さらに高血圧を伴つた高中 性脂肪血症ではかかる変化が有意で，高中性脂肪 血症は高血圧の病態で脳動脈硬化を促進させる因 子として関与するとした. 著者らの成績も脂質異 常群ではそのCBFの推移に明らかな低下がみら れ, 脂質代謝異常が動脈硬化進展, 脳循環障害発 生に関連が深いことを認めた。

\section{B. 脳血管発作前後の脳循環}

脳血管障害患者では， $\mathrm{N}_{2} \mathrm{O}$ 法で測定した全脳平 均血流量が減少していることは既に良く知られて いる ${ }^{9}$. しかし同一症例で媨血管発作前後のCBF 測定を系統的に行ない検討した報告はなく，発作 前より脳血流代謝障害があつたのか，また発作そ のものによつて脳循環障害が生じたのかが不明で あつた，最近，藤島ら に偶然にもRISA法による脳循環測定を行ない, 発 作後も測定を繰返えした 1 例を報告し，発症前日 すでにCBFの低下があり，これは血行障害が発症 に先行する可能性のあることを示唆している．著 者らはやく10年前から高血王患者に $\mathrm{N}_{2} \mathrm{O}$ 法による 脳循環測定を行ない，その後脳血管発作を起こし た12例につき発作後の脳循環を再び測定しえた。

らち発作後 1 力月以内に再測定した10例について は, 発作前に比し推計学的にCBFの有意の減少を 認め, 特に頭蓋内出血や重篤な閉塞性脳血管障害 例に著明であつた， $\mathrm{CMRO}_{2}$ は平均值で減少して いたが推計学的には有意でなかった。このCBF 減 少が発作そのものによる影響の大きいことは，発 作前の $\mathrm{CBF}$ が発作を生じたものと然らさるすのと の間で有意差がなく, 脳血流，代謝の正常なるの からも扢こつて扣り，発作後急激に脳偱環の障害 か゚みられたことからる明らかである。
さらに発作急性期の脳循環代謝障害は, 病巣附 近に限局せず，広く対側半球にまで及び全脳血流 の減少が扣こることが, 脳局所䛻環測定法 ${ }^{11)}$, $\mathrm{H}_{2}$ 法による大脳半球血流測定 ${ }^{12)} に よ り$ 明らかに されている.この理由として発作時の全脳血流減 少は，一側の障書が他側にtransneuralに代謝低下 をきたすことにより，血流減少をるるたらすとい ら Von Monakow ${ }^{18)}$ の提唱したDiaschisisの機序む その一因として㗢くのであるうと考えられてい る.さらにLassen ${ }^{14)}$ も脳硬塞発作後は病巣部古る いはその周辺にischemiaまたはhyperemic foci・.. luxury perfusionを含め…を生ずるとともに，対 側の血流も減少していることを認めている．著者 らの成績では発作時のCBFの急激な減少, その後 の回復とともに推計学的に有意の変化をしめした が，MABPに変動なく， $\mathrm{CMRO}_{2}$ の変化子有意で なかつた，したがつてDiaschisisの機序が働く場合 のように, 脳の血流に先立つて脳代謝の変動が主 役を演じていることをしめす積極的な裏つけはえ られなかつた。

発作時の全脳血流量の減少に関与すると思われ る他の因子として脳浮腫, 頭蓋内王上昇が考えら れる. 脳出血, くも膜下出血, 大硬塞に発作時の CBF減少がが著明なことを考えれば，これら因子 の影響すかなり強いと思われ，これによる二次的 脳代謝障害の可能性も否定できない。

\section{C. 脳血管発作後の脳循環}

脳血管発作後経過を追つて媨循環測定を行ない えた症例につきその予後をみると，軽症の閉塞性 脳血管障害では臨床症状す軽く, $\mathrm{N}_{2} \mathrm{O}$ 法でしめさ れるような全脳血流代謝障害はきたさず， $\mathrm{CBF，}$ $\mathrm{CMRO}_{2}$ の低下を認めない，中等症や頭蓋内出血 では，発作時著明なCBFの減少，それに伴う代謝 低下をみるが，発症 1 カ月以後にはCBFの有意な 増加がみられる。

しかし重症例では発作直後のCBF減少は著し く，その後の血流改善もわるく，人格の荒廃，痴 呆の持続をみている. このように発作時のCBFの 変動は症例により異なり，血流の改善をみるもの 
では, 発作時のtransneural depression, 脳浮腫が 改善していくめのと考光られる. しかし重症例で CBFの改善がみられないのは, 発作時受けた全脳 のischemiaにより脳血管自体あるいは脳神経細胞 の代謝に不可逆的な障害を生じたか, 発作前すで にCBFの減少のあつた症例と考兄られる. 後藤 ${ }^{15)}$ は一定期間血流障害がつら゙くと, 脳血管系に何ら かの器質的変化がおこり, このため血流障害がさ らに持続するという仮説をたてたが，近年Ames III ら ${ }^{16)}$ は家鬼を用い，5〜15分のischemiaののち 血流を再開させても, 血流の回復しない部分が できて，血流遮断時間が長い程広範囲となるこ とをしめし, no-reflow phenomenonと呼んだ. Yamaguchiら ${ }^{17)}$ もュを用いた同様の実験で，脳 細胞にも変性のおこることをしめしている，著者 らの成績はヒトの脳血管障害においても，発作時 著明なischemiaが全脳に生じた場合，no-reflow phenomenon類似の血管変化和よび脳細胞の, 病変 が生ずる可能性を示唆していると考える.

以上の結果から著者らは脳血管障害に打ける発 作前後および発作後のCBFの変動について, 図 6 のごとき一つのシェーマを作成した.

\section{D. 高血圧脳, “血管障害の予後と脳循環}

前述のシェーマにより, 高血圧症, 脳血管障害 の予後を脳循環面から考察する場合，CBFを測定 した時期によって三つに分けるのが妥当と考兄 る.

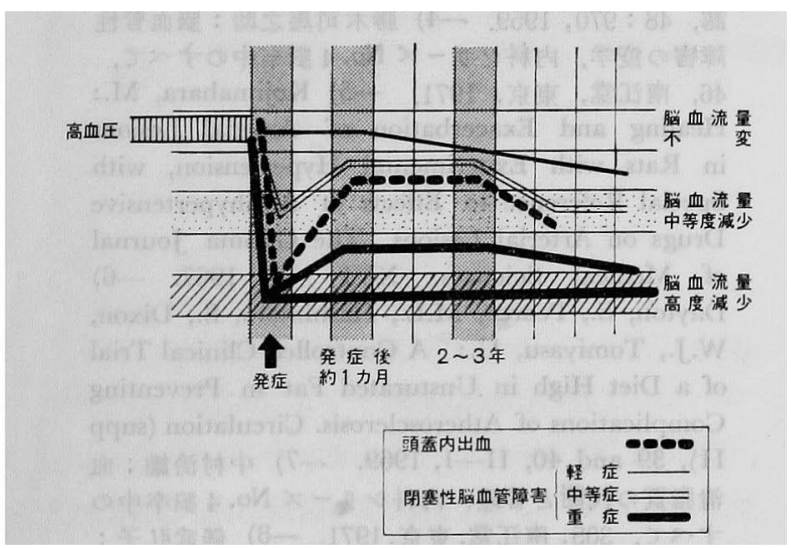

因 6.脳血管発作の䏚血流量の推移
1）高血圧症のCBF： 高血圧は脳血管発作の 基礎的疾患ともいうべきであるが，一般に収縮期 血圧より拡張期血圧が，脳血管障害や虚血性心疾 患と関係が深いとされている. 吉村ら ${ }^{189}$ は拡張期 血圧にCBFをからみ合せCBF測定時血圧が 110を 越光，CBF48以下の老年者は，ほとんど確実に脳 血管障害が予知され，しかも 1 年以内の危険性が あり，さらにCBFとMABPの組合せから調査して る同様であるとのぺている. 著者らは高血圧症の CBFおよびMABPをもつて検討したが，いずれも 脳血管障害を裏付ける値はえられなかつた。

2）脳血管発作 1 カ月以内のCBF : 脳血管発 作直後は全脳血流の急激な減少があり, この時期 のCBFは脳血管そのものの器質的障害の程度をし めさないことがあるため, 再発の予知, 長期予後 にたいして価值がうすいことがある. 脳血管障害 の予後は急性と慢性期に分ける必要があるが，急 性期には生命にたいする予後の予測が主となり， 長期予後を予測することはできない結果がえられ た.

まず頭蓋内出血では発作に引続き死亡するすの が多いため, 著者らの成績ではこのような急性期 のCBF測定例は少なく, 比較的その値は正常値を しめしていた. 閉塞性脳血管障害では発作による 死亡は少なく，死亡を脱しえてもCBFが極端に低 值をしめするのでは, 臥床のまま, あるいは再発 をおこして死亡することを認め, これは発症後の 脳血管が機能的, 器質的に著明な障害をらけてい たものと考えられた． 新ら ${ }^{19}$ ) は脳卒中の脳循環検 查で測定後の生存期間をみ, 早期に死亡するるの ほどCBFの減少が著しいことをみている.

3）脳血管発作 1 カ月以後のCBF : この時期 のCBFは急性期を脱し，生命の危険をま奴れた もののCBFであるため, 脳血管の器質的障害の程 度を反映し，予後に影響するものと思われる．相 沢20)は脳血管障害の予後を脳循環面から検討し, 平均 2 年 5 カ月の観察で生存例と死亡例のCBFの 平均に有意の差があり，また社会復帰面では，そ の程度とCBFには平行関係がみられるとしてい 
る.

著者らの成績でも測定時期により CBFの正常棄 却下限以下の低值をしめするのの予後は極めてわ るく，かかる症例から再発が扣こり，乙かも1年 以内であることがしめされた。これら症例では脳 血管反応性もわるく，治潦にも反応せず，さらに 予後をわるくするるのと想像される．また，再発 までの期間については最初の発作後 1 力年以内で は，脳血管発作の再発が死因となることが多く， 2 年目以後は再発による死亡は少なくなるとされ ているが，著者らの成績でも 1 カ年以内と，午れ 以上たつて再発したもののCBFに有意差を認め た. しかし頭部血流量は発症 3 力月上上 3 年後ま での期間で再発に全く関係がなかったとするもの も市，発症後の経過，予後については全身の栄 養，生活様式，環境および治療など，いるいるの 要因が大きく影響しているものと思われる.

\section{結 論}

1）昭和 36 年より 46 年までの10年間，高血纴 症，脳血管障害 381例について， $\mathrm{N}_{2} \mathrm{O}$ 法による脳 循環測定を同一例につき $1 \sim 7$ 回平均 2 回行な い，高血圧症，脳血管障害の経過括よぴ予後と脳 循環動熊との関連を求めた，高血圧症の経過中 CBFには有意な変化は認めなかつたが，種々の因 子に分類して検討すると，CBF㵊も大きな影響 を与党るものは血圧の管理であつた，肥満そのも のによつてはCBFに影響を及济さないが，肥満者 によくみられる脂質異常はCBFを減少させる方向 飞働く.

2）高血圧から脳血管発作を括こすと，頭蓋内 出血や重症, 中等症の閉塞性脳血管障害ではCBF は有意差をるて減少する．発作後のCBFの推移 は，閉塞性脳血管障害重症例ではCBFの改善はみ られず，中等症は発作直後のCBFは低值でる，後 に有意に上昇する。軽症例では発作後のCBFは注 ১゙正常範囲内にあり，その後も变化しない。

3）発作後 1 力月以上長期CBFの経過は，2 3 年後より低下してゆくものが多い.
4）高血圧時のCBF とその後脳血管発作をきた したものの発症前のCBFとの間には，有意差を認 めなかつた．したがつて高血圧症のCBF值から脳 血管発作を予知することは，必ずしも妥当ではな い. 脳血管発作後 1 カ月以内に測定したCBFは， 発作直後の機能的, 器質的脳循環障害の程度によ り左右されて和り，その值からその後の発作再発 を予測することはできない。

5）脳血管発作後 1 カ月以上経過した時点での

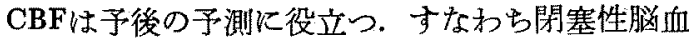
管障害のCBFが低值留るもの，CBFの回復不良 例よりの再発が多い，頭蓋内出血では，生存し党 たものではCBFの回復がよい。

6）高血圧から脳血管発作後のCBFの推移につ き見解を加えると共に，本論文の要旨を一つのシ エーマとして図示した。

（種々御指導，御㻤涟をいたたきき，御校閲下された， 北里大学田崎義昭教授, 鹿応大学後藤文男教授に深甚 の謝意を表する。むた㓍計調查にあたり御尽力いただ

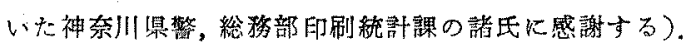

\section{文献}

1) 田崎義昭：高血压症に拉ける脳循環和上び代謝 の砄究, 日内会誌， $45: 731,1956 .-2)$ 後藤文男： 脳循㻴比和的る血圧因子比関寸可研究，精神神経学 誌, $60: 196,1958$. 一3) 中島宏二: 本態性高血圧 症の予後に及活す降王剤長期維持療法の効果に関

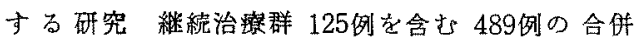
症ならび死亡の発生闰閣する統竍的研究. 日内会 誌, 48：970, 1959. 一4) 勝木司馬之助：睬血管性 障贵の疫学. 内科シリーズ No. 4 睬卒中のすべて, 46, 南江堂, 東京, 1971. -5) Kojimahara, M.: Healing and Exacerbation of Arterial Lesions in Rats with Experimental Hypertension, with Special Reference to Effects of Antihypertensive Drugs on Arterial Lesions. The Gunma Journal of Medical Sciences, XVI: 1, 1967. -6) Dayton, S., Pearce, M.L., Hashimoto, S., Dixon, W.J., Tomiyasu, U.: A Controlled Clinical Trial of a Diet High in Unsturated Fat in Preventing Complications of Atherosclerosis. Circulation (supp II)，39 and 40, II-1，1969. -7) 中村治雄 : 血

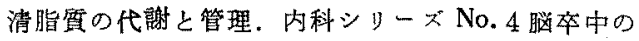
すべて，305, 南江堂, 東京, 1971. -8) 儀武弘子： 血清脂質と脳循環に関する研究，主に血清中性脂肪 
について。度応医学, $46: 271,1969$, -9) Aizawa, T., Tazaki, Y., Gotoh, F.: Cerebral circulation in cerebrovascular disease. World Neurology, 2: 635，1961. -10）藤島正敏，田仲政次郎，格山幸 志郎，尾前照雄，勝木司馬之助：眩幹部血管障害の 脳循環動熊. 臨本神経学, $11: 560 ， 1971$. -11) H $\phi$ edt-Rasmussen, K., Skinh $\phi$ j, E.: Transneural depression of the cerebral hemispheric metabolism in man. Acta Neurol. Scand., 40: 41, 1964.

12) Meyer, J.S., Shinohara, Y., Kanda, T., Fukuuchi, Y., Ericsson, A.D. and Kok, N.K.: Diaschisis resulting from acute unilateral cerebral infarction. Arch. Neurol., 23: 241, $1970 . \quad-13$ ) Von Monakow C.: Die Lokalisation im Grosshirn und Abbau der Funktion durch Kortikale Herde. JF Bergmarim, Wiesboden, Germany, 1914. -14) Lassen, N.A.: The luxury-perfusion synd- rome and its possible relation to acute metabolic acidosis localised within the brain. Lancet, 2: $1113 ， 1966.15)$ 後藤文男：譄血管桩張剤，治療医 学, 1970, 日本臨床, $28: 718,1970$. -16) Ames, III A., Wright, R.L., Kowada, M., Thurston, J. M. and Majno, G.: Cerebral ischemia II, The no-reflow phenomenon. Amer. J. path., 52: 437, 1968. -17) Yamaguchi, T., Waltz, A.G., Okazaki, H.: Hyperemia and ischemia in experimental cerebral infarction: Correlation of histopathology and regional blood flow. Neurology, 21: 565,1971 . -18) 吉村正治, 㛢 紀光: 睬卒 中予知の現況。治港，50:1649，1968，一19）新城 之介，山手昌二，宮崎 正，大中道淳，菊地太郎ほ か: 腷卒中の予後。内科, $22: 1305,1968$, -60) 相沢豊三：媨卒中の臨末一脳循環の立場上り一第 17回日本医学会総会会誌, 1243，1968. 